\title{
ARTICLES
}

\section{Do Characteristics of Consociational Democracies Still Apply to Belgian Parties?}

\author{
Emilie Van Haute \& Bram Wauters
}

\begin{abstract}
Belgium has long been described as a typical case of a consociational or consensus democracy. This article aims at identifying whether political parties in Belgium share the internal characteristics of parties in consensus democracies: passive mass memberships, the importance of purposive and material incentives for joining, and representation of a clear subculture in the social and attitudinal profiles of their members and via overlapping memberships with related organizations. We mobilize longitudinal party membership data and party member surveys conducted in three different time periods. We show that pillar parties still exercise their role of mobilization and representation of societal segments, but these segments tend to become smaller over time. New parties offer alternative options of mobilization and representation, although not always in line with the specific institutional arrangements of consociational democracy.
\end{abstract}

Keywords: Belgium, political parties, party membership, political participation, political representation.

\section{Introduction}

Belgium has long been described as a typical case of a consociational or consensus democracy (Lijphart, 1969; 2012). This model is regarded as effective in maintaining democracy in a country despite deep social divisions that are characteristic of plural societies - 'societies that are sharply divided along religious, ideological, linguistic, cultural, ethnic, or racial lines into virtually separate subsocieties with their own political parties, interest groups, and media of communication' (Lijphart, 2012, p. 31).

Initially, Belgium was labelled consociational by scholars on the basis of the way in which democracy could survive despite deep religious and economic divisions (Huyse, 1970; Lijphart, 1969). Later on, scholars maintained this label, but now tend to refer to relations between language groups (Lijphart, 2012; Pilet, 2005). These three lines of divisions (religious, economic and language divisions) are at

* Emilie Van Haute, Cevipol, Université libre de Bruxelles. Bram Wauters, Research Group GASPAR, Ghent University. 
the source of a deeply segmented society (Lorwin, 1966) divided into subsocieties or 'pillars' (Billiet, 1982; Deschouwer, 2009; Hellemans, 1990; Rokkan, 1977). These 'pillars' encapsulate citizens and organize groups politically and socially through a dedicated political party, a trade union, a social care institution and a multitude of other organizations. According to Deschouwer (2009, p. 5): 'Belgium does indeed fit nicely into this crude description of a typical consociational democracy', with a Catholic pillar, a socialist pillar, and a much smaller liberal pillar, and what could be described as linguistic pillars. Lijphart (2012) and Luther (1999) have stressed the specific role of parties in consociational democracies. Both scholars stress that parties are much more than political organizations: they represent an entire societal segment and support their demands, pacify the subcultures and accommodate divisions at the elite level.

As stated by Deschouwer (1994, p. 80), 'the role played by parties under consociationalism explains a number of characteristics of their internal life'. Luther (1999) identifies three main features of parties in consensus democracies: (1) political mobilization and provision of values/incentives for the subculture, (2) hierarchical party control of the subculture, and (3) organizational penetration and incorporation of the subculture. This article aims at identifying whether in an era of de-pillarization and blurring of social boundaries (Deschouwer, 2009; Dobbelaere, 2017; Méndez-Lago, 2004) political parties in Belgium still share the internal characteristics of parties in consensus democracies. More specifically, we look at the following indicators:

- Mass membership (to measure feature 1);

- Delegation of the search for a consensus from the members to the elites, and low level of political participation and activism (to measure feature 2);

- Purposive and material incentives rather than ideological incentives to join parties (to measure feature 1);

- Overlapping memberships with other organizations from the pillar (to measure feature 3), and

- Social and attitudinal representativeness of a clear subculture (to measure feature 3).

The first part of the article deals with the first three dimensions: mass membership, delegation of power from the members to the party elite and passivity. The second part of the article investigates how parties are (still) representative of a specific subculture in Belgium by looking at both overlapping memberships and representativeness. We use several data sources: longitudinal party membership data (van Haute \& Paulis, 2017) and party member surveys (listed on www. projectmapp.eu, including information on response rates) conducted in three different time periods: data collected by ULB researchers (PS 2003, Ecolo 2004, OpenVLD 2006 and CD\&V 2006; van Haute, Amjahad, Borriello, Close \& Sandri, 2013), data collected by UGent researchers (OpenVLD 2012, N-VA 2012, CD\&V 2013, Groen 2013, sp.a 2015; Wauters, 2017), and brand new data collected in 2016 and 2018 within the international MAPP project. For the Belgian part of this MAPP-survey, all parties represented in the federal parliament received an invitation to participate. To date, six parties (Ecolo in 2016 and CD\&V, Groen, 
N-VA, sp.a and OpenVLD ${ }^{1}$ in 2018) have participated in the project and have distributed the online survey. In total, 12,639 members filled in this questionnaire, making this the largest party member survey ever in Belgium. The various types of data we use can be considered a robustness check of our findings throughout time.

By analysing parties' internal life, this article indirectly refers to the role played by parties in Belgium's democracy. In doing so, it contributes to an evaluation of the extent to which Belgium still fits Lijphart's model of consociational democracy at its very core. Indeed, as Deschouwer points out (2009, p. 8), 'the cleavages on which the pillarized organization of Belgian society was built have now deeply eroded'. If this statement holds, our analysis should show a transformation of parties in these core characteristics.

\section{Party membership levels}

The available data on party membership in Belgium based on parties' own records tends to confirm that mass membership has sharply declined in Belgium (van Haute \& Paulis, 2017). In particular, the parties embodying the idea of pillar parties (Christian Democrats - CD\&V and CDH, and Social Democrats - sp.a and PS) have seen their membership numbers decline drastically since the early 1990s (Table 1). They have sometimes more than halved their membership figures in two decades: the CD\&V went from 120,000 to 60,000 , the $C D H$ from 30,000 to less than 15,000, and sp.a peaked near the 100,000 mark to drop below 45,000 in 2014. The PS has also faced a sharp decline, from up to 160,000 members in the early 1980s, to stabilize between 80,000 and 90,000 in the 2000s.

The Liberals (OpenVLD, MR) have their roots as a cadre party. They had never fully embraced the mass membership feature of the other pillar parties. Over time, they have faced fluctuations but are characterized by stability in the long term: around 65,000 for the OpenVLD and between 25,000 and 30,000 for the MR.

Mass membership may be a feature from the past, but party membership is not. Other parties in the party system have faced brighter trends. The Greens (Groen, Ecolo) have experienced a growth until early 2000s, followed by a decline after their governmental participation at the national level. Both parties have recovered, albeit at a different pace, to stabilize around 6,000 members. As for the Regionalists (VU and N-VA, DéFI), the VU faced a peak in the 1970s, concomitant with its electoral peak. The next two decades were characterized by a sharp decline in membership levels that split the party. The N-VA picked up the VU's membership and regrew it (in line with their electoral growth) to reach around 40,000 in the mid-2010s. DéFI has always been a much smaller party, mainly restricted to Brussels and its periphery. At its peak in the 1970s it declared 15,000 members, down to around 5,000 mid-2010s.

The Flemish Radical Right (VB) was characterized by constant growth of membership, which peaked at 25,000 in 2010. The party's membership declined, for the first time, in the first half of the 2010s, to 17,000. The Radical Left (PVDA-PTB) 
is characterized by membership growth in the 21st century and declared in the mid-2010s to have around 10,000 members in Belgium (as this is the only 'national' party in Belgium).

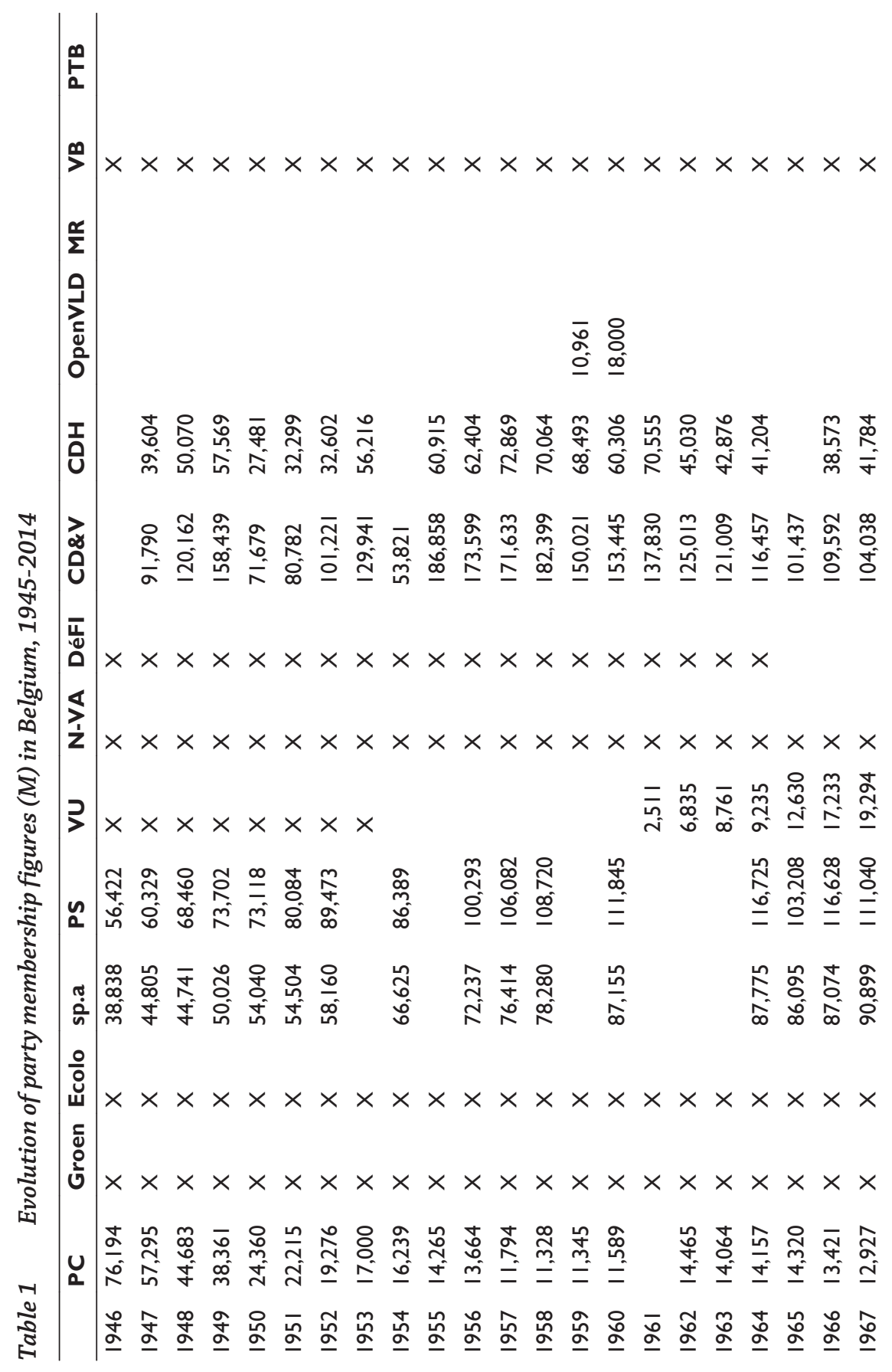




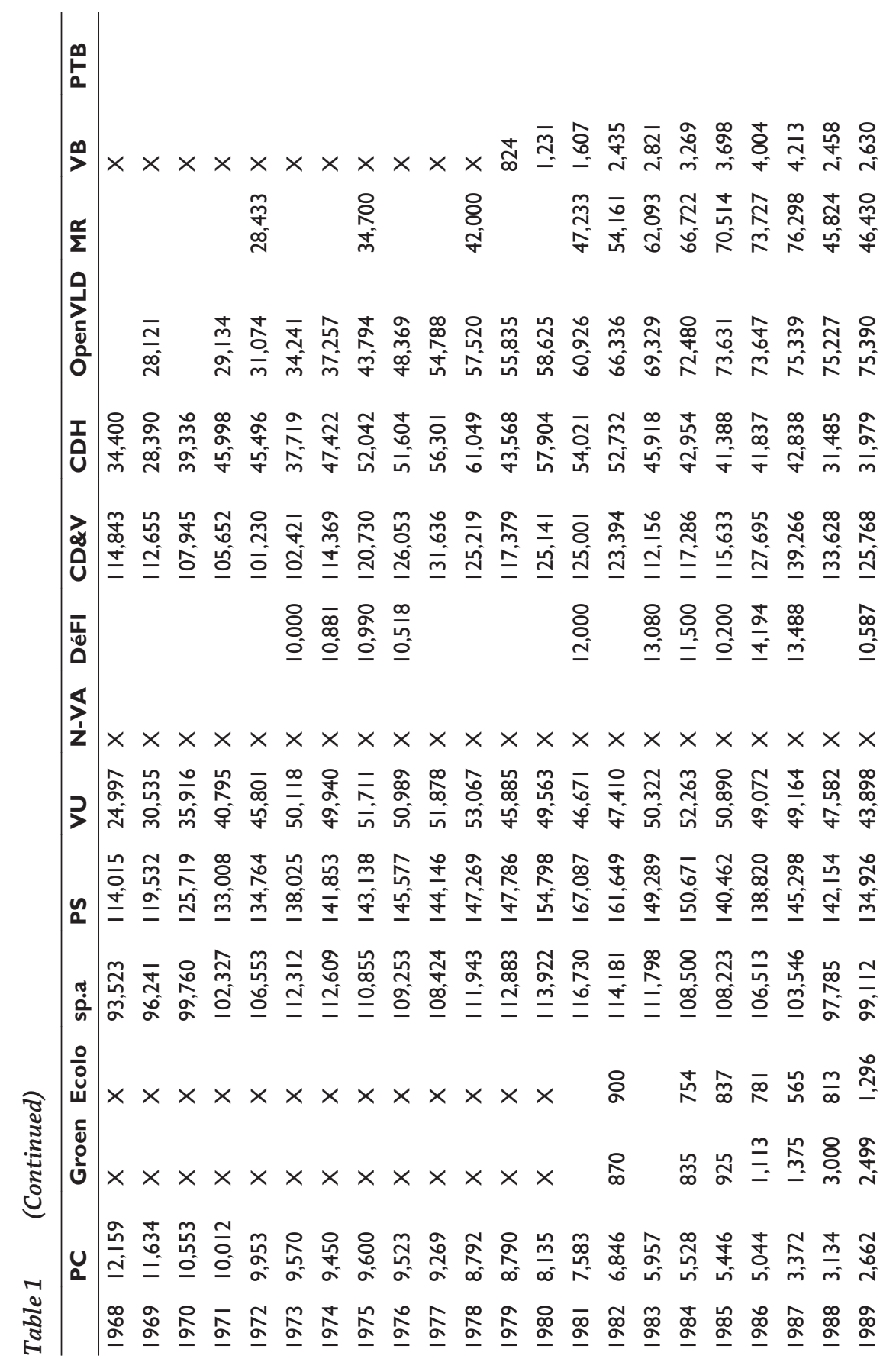




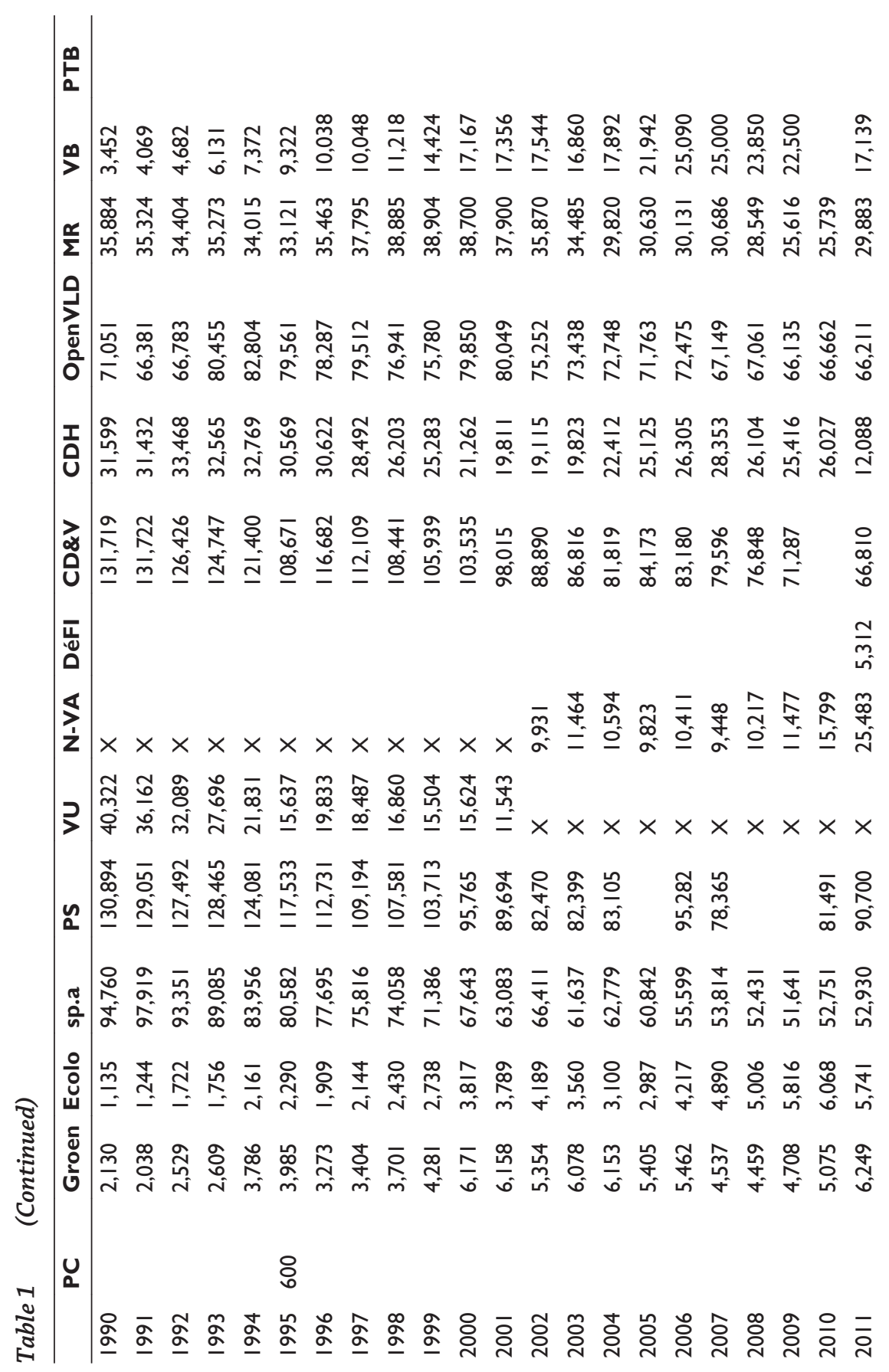




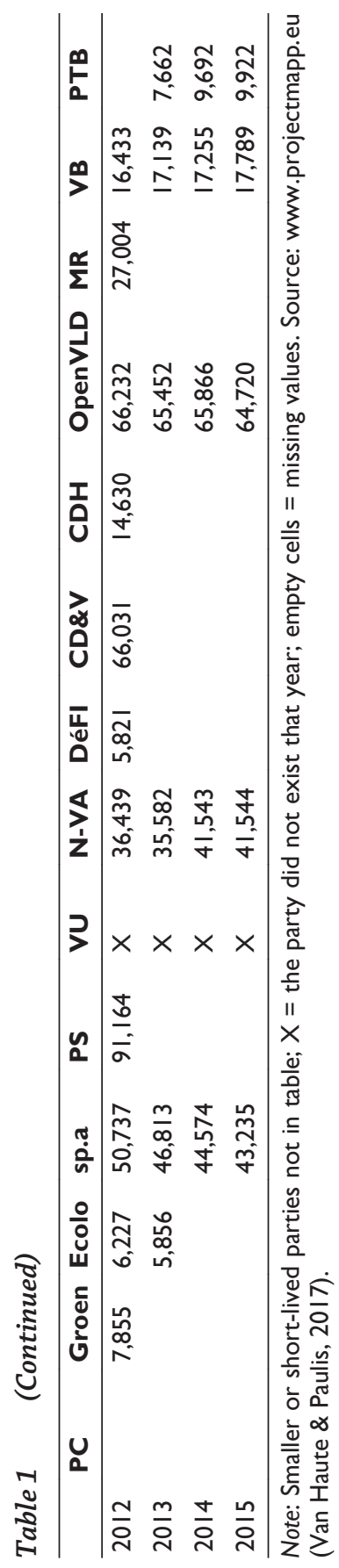




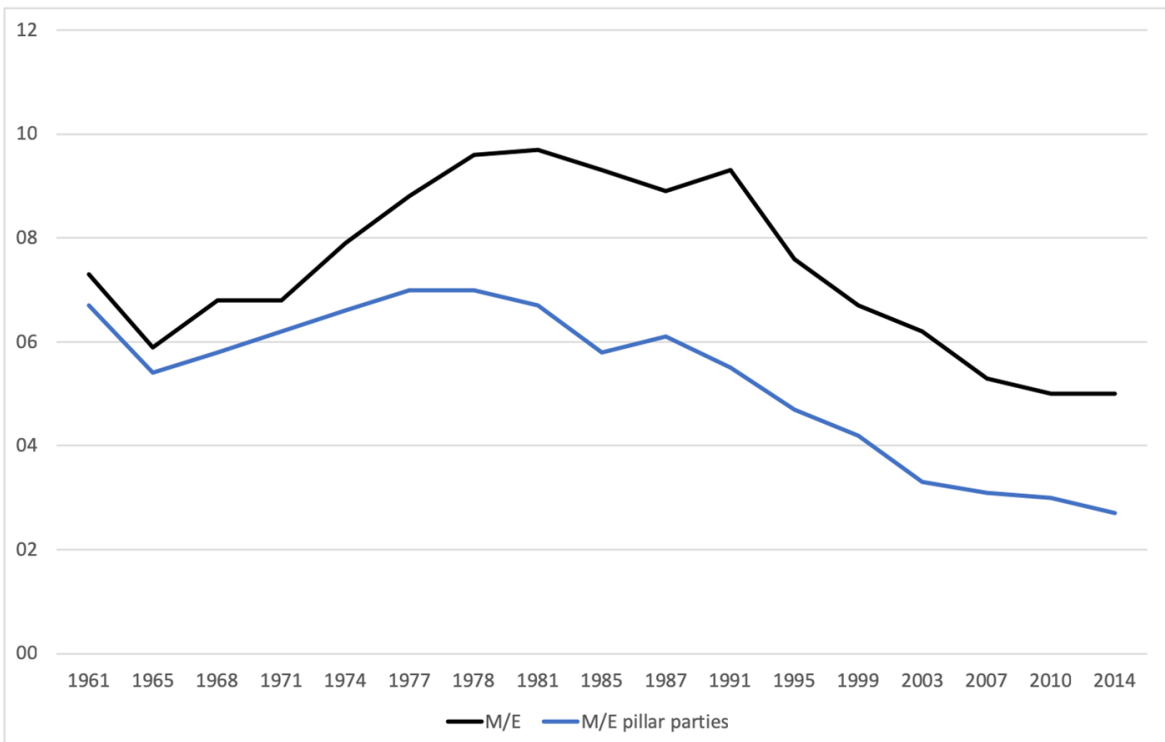

Note: Total number of party members (M) sometimes calculated with missing values (1961: Frenchspeaking Liberals; 1965: FDF and French-speaking and Flemish Liberals; 1968: DéFI and Frenchspeaking Liberals; 1971, 1995, 1999, 2003: DéFI; 2007: DéFI). For some election years, data is an estimate based on the previous year, the next year or an average between the two (24 observations). Source: www.projectmapp.eu.

Figure 1 Evolution of party membership ratio to the electorate for pillar parties (Social Democrats and Christian Democrats) and all parties $(M / E)$ in Belgium, 1961-2014

Figure 1 summarizes these trends and presents the party membership ratio $(\mathrm{M} / \mathrm{E})$ in Belgium over time. It is a relative measure of the total number of members of the electorate at the country level. It depicts the percentage of voters who are members of a political party. In the early 1960s, about $4 \%$ of voters in Belgium were also members of a political party. This proportion grew to almost $10 \%$ at the end of the 1970s and stabilized in the 1980s. The 1990s and 2000s were characterized by a decline that brought the membership ratio back to around $5 \%$. This ratio has stabilized in the 2010s.

In comparative terms, the membership ratio has always been higher in Belgium than in most European countries (van Biezen, Mair \& Poguntke, 2012). At the end of the 1990s, Belgium was among the top five (out of 20) of the countries with the highest membership ratio in the EU, alongside Austria, Cyprus and Italy, other countries often characterized as consensus democracies. It still ranked 6th out of 27 in 2008 and second last in terms of membership losses. 
Thus, overall, the analysis reveals a clear drop in mass membership in the former pillar parties, which severely affects the country's overall membership ratio. As Marien and Quintelier (2011) have shown, group memberships in general are eroding. This partly explains the decline in mass membership for the Christian Democrats and the Social Democrats in Belgium, as group membership in other related organizations constituted a large reservoir of members for pillar parties via overlapping memberships (see below). New parties have only partly benefited from this. In Flanders, it is especially the case of VB and Groen in the 1990s and 2000s, and the N-VA in the 2010s. The growth of the N-VA could be a sign of a new pillarization on the linguistic divide, with the N-VA trying to occupy the position of the pillar party embodying the Flemish side of that cleavage. However, these new parties have been unable to attract members at the same rate as former pillar parties in the 1970s and 1980s, and this explains the overall decrease in the $\mathrm{M} / \mathrm{E}$ ratio.

It is necessary, however, to temper these conclusions with the following nuances. First, as Figure 1 shows, the membership ratio is today very similar to what it was fifty years ago (in the 1960s). As Scarrow (2000) points out, the comparison over time always depends on the starting point that is taken for that comparison. In that regard, the very high levels of the 1970s and 1980s can be regarded as the exception rather than the norm.

This exceptional situation could occur, at least partially, owing to errors in the membership logs of parties. These errors may be involuntary and related to the difficulties of maintaining a membership list up to date in those days without the modern tools and technologies. Today, the information can easily be shared between the central level and local branches, and each individual fee can be traced back to an individual member via bank transfer references. These errors may also be part of a purposive strategy. Parties are not exempt from internal battles between local branches. As a party secretary confided (interview, 19 January 2016), the membership figures were crucial for local branches, as they determined the allocation of delegates at the party conference. Local branches sometimes paid fake membership fees in order to inflate their number of delegates, and hence their weight at the party conference, up to the point that some even faced bankruptcy. These voluntary inflations have become less important since most parties have replaced their representative system with party delegates by a direct involvement of individual members (for both leadership selection and participation in party conferences) (Pilet \& Wauters, 2014).

Another indication is that in recent decades, the subjective measures of party membership based on population surveys (in which respondents are asked whether they are members of a political party) have tended to converge with the objective measure based on parties' declarations much more than in the past. Marien and Quintelier (2011, p. 56) emphasized that for the 1980s and 1990s, the membership ratio based on parties' declaration is two or three times higher than the ratio based on population surveys. Since the end of the 1990s, both ratios have been much closer.

The 2009 Partirep Voter survey conducted in Flanders and Wallonia showed that $5.7 \%$ of the respondents were members of a party $(7.7 \%$ in the 2014 Partirep 
Voter Survey) and that $4.8 \%$ were former members (7.2\% in 2014). Besides, in $2014,6.5 \%$ of the respondents declared that they were not party members but nevertheless had been participating in party activities. This means $78.5 \%$ of the respondents never had a link with parties. These proportions are close to what we find on the basis of parties' reported memberships.

These nuances point to the fact that mass membership seems to be an exception that concerned only certain parties (Christian Democrats and Social Democrats) at a very specific point in time (1970s and 1980s), partly owing to the specificities of pillar parties in Belgium, but also owing to other more pragmatic factors.

\section{Political participation and party activism}

The second feature of parties in a pillarized society is, traditionally, the low level of political participation and party activism.

In 1975, an internal party member survey had highlighted the low level of activism of members of the Flemish Christian Democrats (CD\&V, then CVP):

Not all members are convinced followers. No less than a quarter of the members think that their bond with the party is "weak" or that they are "at odds" with the party. The number of active members amounts to $30 \%$ according to the same survey (cited in Dewachter, 2003, p. 262).

Twenty years later, Deschouwer and Opsomer (1993) pointed out that there was no negative trend in activism in Belgium but rather that activism varied according to parties, with new parties (Regionalists and Greens) having more active members than pillar parties. This is also what van Haute et al. (2013) emphasized on the basis of party member surveys. Members of pillar parties are the least active, as reflected by the declaration of a majority of members that they devote no time at all to their party (52\% in the PS, $57 \%$ in the CD\&V and up to $63 \%$ in the OpenVLD), as opposed to a quarter of the French-speaking Greens (Ecolo). Also Devroe and Van de Voorde (2017) find that most party members are not very active in their parties, although it depends on the kind of activity (more into campaign activities) and the kind of party (Groen members are most active, N-VA least active).

The results of the recent MAPP surveys show that these figures are still very stable: a quarter of the French-speaking Greens do not devote any time to their parties (Ecolo 2016). This amounts to a third for the pillar parties (35.4\% for sp.a 2018) and up to $40.8 \%$ for N-VA (2018). This is in line with other existing studies (van Haute, 2015).

Thus, there is no clear decline in levels of activism among party members. The specificity is in the contrast across parties in Belgium. In line with our expectation, Green party members are, on average, more active than members of former pillar parties. What stands out is the (recent) low rate of activism of members of the N-VA (especially also in comparison with its predecessor VU). This could be 
another sign that this party recently displayed at least some features of a pillar party (large but passive membership).

The nature of party activism has also changed over time in response to the changing role that parties assign their members. Under the pressure of the rise of new parties, membership decline and the wish to strengthen the position of the party leader (Wauters, 2014), almost all Belgian parties (including pillar parties) have taken on board the rhetoric of internal democratization. By democratization, parties have meant more inclusiveness, that is, replacing the delegation mechanisms by a more direct say to their members (OMOV - one member one vote) in the core decision-making processes such as leadership selection (Pilet \& Wauters, 2014) and manifesto formulation. At the same time, party executives have managed to retain control and leadership strength (Deschouwer, 1994, p. 87). In particular, they have managed to control candidacies for leadership elections via stricter conditions and the mechanism of an 'ad interim' party leader: putting the party executive's preferred candidate as interim leader a couple of months ahead of the election to send a signal to the members that this is the 'legitimate' party leader to elect over potential challengers. Ultimately, in almost $50 \%$ of the leadership elections using the OMOV system, only one candidate was running, and in the majority of the other cases, there was no real contest. The average margin between the top two finishers is 30.5 percentage points (Pilet \& Wauters, 2014, p. 39).

\section{Incentives to join parties}

Lastly, pillar parties would be characterized by different motivations for joining and by higher levels of processual and material motivations and lower levels of ideological motivations. Over time, we would expect that de-pillarization should re-ideologize parties and party membership.

Our results tend to confirm the first pattern (Table 2). When asked about their reasons for joining the party, members of the Flemish Christian Democrats and Social Democrats display the highest levels of material incentives (joining for a career or job), of joining owing to social habit, or to meet people and acquire new skills (although Ecolo scores high on this last dimension too). Members of these pillar parties also display the lowest levels of ideological motivations. Interestingly, pillar parties also show higher levels of members stating that they joined in continuation of prior engagements or with a view to promoting a specific issue, which we may relate to the overlapping memberships that characterize pillar parties (see also below). Conversely, new parties distinguish themselves by higher (N-VA) and lower (Groen, Ecolo) levels of members who joined to support the party. The high levels among the N-VA might reflect the newness of the party. The weight of ideological incentives in the recruitment patterns of the N-VA makes a strong case against characterizing it as a pillar party.

As regards change over time, differences in the questions asked in prior surveys preclude a systematic comparison. However, previous findings also pointed to 
Table 2 Reasons for party members' joining (1-4)

\begin{tabular}{llllll}
\hline & $\begin{array}{l}\text { CD\&V } \\
\mathbf{2 0 1 8}\end{array}$ & $\begin{array}{l}\text { Groen } \\
\mathbf{2 0 1 8}\end{array}$ & N-VA 2018 & sp.a 2018 & Ecolo 2016 \\
\hline Party support $^{1}$ & 2.4 & 2.2 & 2.7 & 2.4 & 1.8 \\
Processual incentives $^{2}$ & 2.8 & 2.4 & 2.4 & 2.6 & 2.8 \\
Material incentives $^{3}$ & 1.7 & 1.4 & 1.4 & 1.6 & 1.3 \\
Social habit $^{4}$ & 3.0 & 2.0 & 2.1 & 2.6 & 1.4 \\
Issue $^{5}$ & 2.6 & 2.2 & 2.0 & 2.6 & 2.5 \\
Ideological incentives $^{6}$ & 2.8 & 3.1 & 3.3 & 3.0 & 3.2 \\
\hline
\end{tabular}

' Scale built on the following items: 'To support the party financially', 'To support a candidate for elections', 'To support a candidate for the party's leadership', and 'Because I had a great appreciation of the leader of the party'. Cronbach's alpha $=0.744$.

${ }^{2}$ Scale built on the following items: 'To meet interesting people and extend my social life/participate in social activities', 'To get new skills and/a better understanding of politics', 'To meet politically like-minded people'. Cronbach's alpha $=0.754$.

${ }^{3}$ Scale built on the following items: 'Because I wanted to pursue a political career in the party' and 'I thought it would help my career/to get a job'. Cronbach's alpha $=0.586$.

${ }^{4}$ Scale built on the following items: 'It was customary in my environment', and 'Because someone asked me to'. Cronbach's alpha $=0.477$.

${ }^{5}$ Scale built on the following items: 'It was a continuation of other engagements', and 'I wanted to influence the party on a particular issue'. Cronbach's alpha $=0.329$.

${ }^{6}$ Scale built on the following items: 'Because I believed in what the party stands for' and 'To oppose other political parties'. Cronbach's alpha $=0.436$.

Source: MAPP surveys; Note $=\mathrm{I}=$ not important at all; 4 = very important.

higher levels of material incentives among the pillar parties ( $C D \& V$, PS and OpenVLD) and lower levels among the Greens (Ecolo) that displayed higher levels of ideological motivations (van Haute et al., 2013). Thus, the path to party membership still tends to differ across parties.

\section{Social representativeness}

The last two features that we investigate are the social and attitudinal representativeness of party members and their overlapping memberships, in order to identify whether they (still) represent a clear subculture.

To this end we investigate the extent to which political parties are composed of traditionally related social groups. More specifically, we are interested in religion and profession, two of the traditional cleavages on which the party system in Belgium has been built (Huyse, 1970; Lipset \& Rokkan, 1967). We also investigate whether parties are characterized by overlapping memberships of specific 'pillarized' organizations, including trade unions and public health insurance companies.

In terms of religious orientation of party members (Table 3), the results clearly reflect the traditional patterns in terms of religious attachment: the Flemish Christian-Democratic Party (CD\&V) is almost entirely composed of Roman Catholics (89\%), while the sp.a and also both Green parties (Groen and Ecolo) are largely composed of non-believers $80.7 \%, 70.8 \%$ and $65.1 \%)$. These findings are 
Table 3 Religious orientation of party members (\%)

\begin{tabular}{llllll}
\hline & $\begin{array}{l}\text { CD\&V } \\
\mathbf{2 0 1 8}\end{array}$ & $\begin{array}{l}\text { Groen } \\
\mathbf{2 0 1 8}\end{array}$ & N-VA 2018 & sp.a 2018 & Ecolo 2016 \\
\hline Roman Catholic & 89.0 & 23.0 & 51.4 & 14.9 & 26.2 \\
No religion & 9.4 & 70.8 & 45.2 & 80.7 & 65.1 \\
Other & 1.6 & 6.2 & 3.4 & 4.4 & 8.7 \\
\hline
\end{tabular}

Source: MAPP surveys.

in line with earlier research that found that the OpenVLD (2006) and the PS (2003) also relied on non-believers, although the Greens have changed on this characteristic in the last decade, counting more non-believers among their members (Devroe, de Vet \& Wauters, 2017; van Haute et al., 2013). The proportion of Roman Catholics among the $C D \& V$ is only slightly lower than in previous surveys (97.2\% in 2006 and 92\% in 2013). The N-VA presents itself as a party cutting across the religious cleavage: it is composed almost equally of Roman Catholics and non-believers.

In regard to religious practice (not in the table), $C D \& V$ members are most active, but only $23 \%$ of $C D \& V$ members go to church every week. These trends are linked to the secularization of Belgian society, but despite that, the lines are still very clearly defined across parties.

Another cleavage on which the Belgian party system is built is the socio-economic cleavage, embodied here by the professional occupation of party members. Again, distinctive patterns emerge (Table 4). N-VA counts most self-employed and business owning party members (22\%), while for the Social-Democratic party, sp.a, the largest proportion of their members works in the public sector broadly defined (59\%). N-VA has also relatively the largest group of members working in the private sector (39\%). OpenVLD (in 2006) presents a similar profile, with a high proportion of self-employed and business owners compared with the case in other Flemish parties. The OpenVLD also had a majority of its members working in the private sector. The differences among other parties are smaller. The sp.a and the PS, and, to a lesser extent, Groen and Ecolo have a majority of their members working in the public sector. The $C D \& V$ has the most transversal profile in terms of professional status of its members but was and still is characterized mainly by a large proportion of members who are retired.

\section{Overlapping memberships}

In consociational democracies such as Belgium, parties are the voice not simply of a specific group, but of specific pillars composed of several organizations most often combining religious and socio-economic affiliations (Lijphart, 1969). One feature of pillar parties is overlapping memberships, that is, party members who 
Table 4 Professional occupation of active party members

\begin{tabular}{llllll}
\hline & $\begin{array}{l}\text { CD\&V } \\
\mathbf{2 0 1 8}\end{array}$ & $\begin{array}{l}\text { Groen } \\
\mathbf{2 0 1 8}\end{array}$ & N-VA 2018 & sp.a 2018 & Ecolo 2016 \\
\hline $\begin{array}{l}\text { Self-employed/business } \\
\text { owner }\end{array}$ & 16.3 & 11.0 & 22.7 & 6.1 & 12.6 \\
$\begin{array}{l}\text { Employed by a private } \\
\text { company }\end{array}$ & 36.3 & 36.6 & 39.6 & 34.6 & 35.8 \\
$\begin{array}{l}\text { Employed in the public } 47.4 \\
\begin{array}{l}\text { sector (hospital, } \\
\text { school, government } \\
\text { agency, etc.) }\end{array}\end{array}$ & 52.4 & 37.7 & 59.3 & 51.6 \\
\hline
\end{tabular}

Source: www.projectmapp.eu

are also affiliated to other organizations of the pillar, which facilitates recruitment.

Not much data is available for the early years. Dewachter (2003, p. 262) refers to an internal survey that was conducted among the Flemish Christian Democrats (then CVP) in 1975, which reveals that

[a]lmost two-thirds of active CVP members are also members of a socioprofessional organization and $41 \%$ are also members of a cultural association. About a quarter of these members are also active in these organizations. The group of militants is of course much broader than that of the active members.

Clearly, the party was characterized by overlapping memberships with those of certain other organizations, which we can assume were related to their pillar. In order to determine whether this is still the case, we rely here on data pertaining to trade union membership (Devroe et al., 2017).

Only the Social-Democratic party has a majority of its members affiliated to a trade union (Table 5) and almost exclusively with the union related to the socialist pillar (ABVV-FGTB). The same goes for the PS (2006, not in the table). In other parties, union members are not a majority, but we can nevertheless distinguish the same patterns on which the Belgian party system has been built: members of the $C D \& V$ are almost exclusively affiliated to the Christian trade union (ACV-CSC), and a very large majority of the members of OpenVLD affiliated to the (smaller) liberal trade union (ACLVB-CGSLB). The members of the Green parties tend to be affiliated to the two main unions, while those of N-VA display the lowest level of unionization, and when affiliated their members tend to choose the Christian trade union. The same patterns are replicated when we analyse membership of health insurance companies.

In sum, it is striking to see how former mass-pillar parties are still very much recruiting in their classe gardée and are dominated by overlapping memberships. The Christian Democrats, Social Democrats and Liberals clearly continue to recruit in their own societal segments. What is also striking is that sister parties 
Table 5 Trade union membership of party members

\begin{tabular}{llllll}
\hline & $\begin{array}{l}\text { CD\&V } \\
\mathbf{2 0 1 3}\end{array}$ & $\begin{array}{l}\text { Groen } \\
\mathbf{2 0 I 3}\end{array}$ & N-VA 20I2 & $\begin{array}{l}\text { OpenVLD } \\
\mathbf{2 0 1 2}\end{array}$ & sp.a 20I5 \\
\hline ACV-CSC & 37.0 & 28.8 & 16.6 & 6.0 & 4.6 \\
ABVV-FGTB & 0.6 & 15.8 & 3.4 & 0.7 & 47.2 \\
ACLVB-CGSLB & 0.2 & 1.4 & 1.1 & 13.7 & 0.9 \\
No trade union & 62.1 & 53.2 & 78.1 & 76.3 & 47.2 \\
\hline
\end{tabular}

Source: Devroe et al. (2017).

on the two sides of the linguistic border share very similar features. We only have some elements of comparison for the Social Democrats and the Greens, but they clearly point to similarities, as shown for other aspects of sister parties (Deschouwer, Pilet \& van Haute, 2018). Finally, it should be noted that these features are eroding but at a very slow pace.

\section{Attitudinal representativeness}

In this section, we investigate whether the representation of different segments of society in parties also applies to opinions about policy issues. In other words, we analyse the extent to which party members are representative of certain sides of cleavages and incarnate democratic pluralism.

We start by analysing where party members position themselves and their parties on a classic left (0) to right (10) scale (Table 6). Our results show clear differences in left-right orientation between members of different parties. N-VA members are more rightist than $C D \& V$ members, who in their turn are more to the right than members of Groen, Ecolo and sp.a. However, this distribution on the leftright scale masks the diversity of issues that divide Belgian society and that lay at the origin of the development of a plurality of parties.

In order to capture this, we examine more closely the differences in opinions between parties by looking at five policy dimensions on which parties originated (or have realigned on). These dimensions include globalization (attitude towards migration and the European Union), the socio-economic dimension (opinion about the role of the government in wealth redistribution), the moral-ethical dimension (opinion on issues such as same-sex marriage and abortion), the postmaterialism dimension (opinion on whether protection of the environment or stimulating the economy should gain priority) and the decentralization dimension (opinion on more autonomy for the regions in Belgium).

Our results show that members of different parties clearly differ on all dimensions of these issues (confirmed by Anova analyses). Party members tend to differ the most from members of other parties on issues that could be considered the 'core business' of their party. It is the case for the Christian Democrats ( $C D \& V)$, who position themselves the furthest on the conservative side of the progressiveconservative scale. It is also the case of the Social Democrats (sp.a), who position 
Table 6 Average position of party members on policy scales

\begin{tabular}{|c|c|c|c|c|c|}
\hline & $\begin{array}{l}\text { CD\&V } \\
2018\end{array}$ & $\begin{array}{l}\text { Groen } \\
2018\end{array}$ & N-VA 2018 & sp.a 2018 & Ecolo 2016 \\
\hline Left-Right (0-10) & 5.6 & 2.8 & 7.3 & 2.9 & 2.9 \\
\hline $\begin{array}{l}\text { Globalization:' open } \\
\text { vs. closed (I-5) }\end{array}$ & 2.9 & 2.2 & 3.6 & 2.8 & 2.2 \\
\hline $\begin{array}{l}\text { Socio-economic: }{ }^{2} \text { left } \\
\text { vs. right }(I-5)\end{array}$ & 2.7 & 2.1 & 3.4 & 2.1 & 1.8 \\
\hline $\begin{array}{l}\text { Moral-ethical: }{ }^{3} \text { pro- } \\
\text { gress vs. conservative } \\
(\mathrm{I}-5)\end{array}$ & 2.4 & 1.7 & 2.0 & 1.7 & 1.7 \\
\hline $\begin{array}{l}\text { Post-materialism: }{ }^{4} \\
\text { environment vs. econ- } \\
\text { omy (I-5) }\end{array}$ & 2.6 & 1.5 & 2.8 & 2.1 & 1.4 \\
\hline $\begin{array}{l}\text { Decentralization: }:^{5} \text { Bel- } \\
\text { gium vs. Flanders (I-5) }\end{array}$ & 2.9 & 2.2 & 4.3 & 2.3 & 2.4 \\
\hline
\end{tabular}

' Scale built on the following items: 'Immigrants are good for this country's economy' and 'Our country on balance has benefited from being a member of the European Union' and on these reversed coded items: 'Immigrants should be required to adapt to the customs of this country', 'Immigration represents a serious threat to our national identity', 'European integration has gone too far'. Cronbach's alpha $=0.822$.

${ }^{2}$ Scale built on the following items: 'Providing social services should be the prime goal of government' and 'Income and wealth should be redistributed towards ordinary people' and on these reversed coded items: 'The government should abstain from intervening in the economy', 'Many public services could be run better and more cheaply if they were privatized', 'Too many people receive social benefits without really needing them'. Cronbach's alpha $=0.729$.

${ }^{3}$ Scale built on the following items: 'Women should be free to decide on matters of abortion' and on this reversed coded item: 'Same-sex marriages should be prohibited by law', 'We believe too often in science and not enough in feelings and faith'. Cronbach's alpha $=0.508$.

${ }^{4}$ Scale built on the following item: 'Stronger measures should be taken to protect the environment' and 'Our country should implement a carbon tax' and on these reversed coded items: 'Nuclear power stations are the solution for a shortage of energy in the future'. Cronbach's alpha $=0.610$.

5 Scale built on the following reverse coded items: "More power should be delegated to the regions' and 'The solidarity between the regions of our country is necessary but it has gone too far'. Cronbach's alpha $=0.784$.

Note: Variances are always equal, Anova: $F($ glob $)=2148.446^{* * *}, F(\mathrm{soc})=3201.326^{* * *}, F(\mathrm{mor})=$ $539.308^{* * *}, F(\mathrm{env})=1470.087^{* * *}, F(\mathrm{dec})=4516.765^{* * *}$.

Source: MAPP surveys.

themselves the furthest on the left side of the socio-economic scale, albeit together with the Greens (Groen, and Ecolo). The members of Groen and Ecolo position themselves the furthest to the post-materialist side of the environmenteconomy scale. Similarly, they are of the furthest open side of the globalization scale and opposed to the members of the N-VA on that scale. The N-VA members are the furthest on the 'Flanders' side for the decentralization scale.

Differences between members of all parties are the largest for the decentralization dimension and the globalization dimension, and the smallest for the moralethical dimension. Although for a number of policy dimensions, the members of Groen and sp.a display very similar positions, the differences on the globalization 
and post-materialism scales are more marked. These results confirm findings based on previous surveys (Bouteca, Devos \& Van de Voorde, 2017). And it is also again striking to see the similarities in the positions of members from the same party family (Greens), as Deschouwer et al. (2018) had shown for other party levels (MPs and voters).

All this clearly emphasizes that party members in Belgium differ ideologically and represent different societal groups with different interests and opinions. Despite claims about ideological convergence between parties (Downs, 1957; Fukuyama, 1992; Meguid, 2005), our data clearly shows that party members do not think alike.

\section{Conclusion}

In this article we set out to identify whether political parties in Belgium share the internal characteristics of pillar parties in consensus democracies. More specifically, we investigated whether pillar parties are (still) characterized by whether passive mass memberships, purposive and material incentives are important for joining, and representation of a clear subculture in the social and attitudinal profiles of their members and via overlapping memberships with related organizations. We showed that high levels of mass membership are an exception that concerned only the main pillar parties (Christian Democrats and Social Democrats) at a very specific point in time (1970s and 1980s). Our analysis revealed that this exceptional feature is partly due to the specificities of pillar parties in Belgium, but also due to other more practical factors. If mass membership is a feature mainly from the past, party membership is not. Other parties (Greens, Regionalists, Radical Right and Radical Left) have faced membership stability or growth, albeit never in the proportions of former mass membership parties. The N-VA is an exception in this regard, as the party achieved high membership levels that rival the current levels of former pillar parties. We can conclude that current party membership levels are lower than they used to be but that it also depends on the point of reference.

We have also shown that activism is lower in pillar parties, with little change over time, in contrast to the case with other parties, especially the Greens, which display higher levels of party activism. Again, the N-VA recently stands out with a passive membership. This tends to confirm what Weldon (2006) had noted: smaller polities tend to display higher participation rates.

But pillar parties are not characterized by mass membership alone. The nature of membership also differs, especially insofar as the role granted to members and the membership recruitment patterns are concerned. In terms of role and rights granted to members, pillar parties in Belgium have been pushed to adopt more inclusive decision-making processes, especially in regard to designating the party leader. Today, members tend to exercise rights previously granted to party delegates. However, various mechanisms ensure that the party executive still exerts a tight control over the leadership selection process. Besides, our analysis confirms that the incentives for joining still differ across parties and that pillar parties are 
characterized by higher proportions of members who declare that material and social reasons were important in their decision to join the party. Conversely, other parties display higher proportions of members who cite ideological reasons for joining. These results are consistent over time and do not reveal strong changes in the incentive structure of pillar parties.

The profile of members who are recruited by pillar parties is also rather stable over time. Pillar parties still overwhelmingly recruit members who are representative of a specific subculture, be it in terms of religious orientation, socio-economic status or overlapping memberships. Despite major societal changes, pillar parties have a hard time recruiting beyond their classe gardée. This can also explain why they are facing membership erosion. All parties also recruit members who clearly adopt distinctive policy positions, especially on the cleavage that forms the 'core business' of the party. What our results show is that these profiles are very congruent across the linguistic border, between parties from the same family. While we do not have data from all parties to support that claim, it tends to confirm what Deschouwer et al. (2018) have shown about sister parties in Belgium: despite fewer contacts, the social and ideological profiles are still very similar.

By analysing parties' membership base, this article addresses the role played by parties in Belgium's democracy and the extent to which Belgium still fits the model of consociational democracy. Our analysis shows that despite deep societal changes, pillar parties did not face major transformations in their core characteristics.

Understanding the characteristics and roles of parties in relation to subcultures over time is crucial. In consociational democracies, the role of parties in representing these social divisions is traditionally translated into institutional arrangements and political practices. In terms of institutions, Lijphart (2012) especially focuses on how this relates to executive power sharing in broad coalition cabinets, relatively weak executives, a multiparty system, proportional representation, interest group corporatism, federalism, bicameralism, constitutional rigidity, judicial review and central bank independence. Politically, segmentation is related to power sharing between elites and autonomy of the subsocieties.

Our analysis points to societal changes that were not translated into party change for pillar parties or into institutional changes in regard to the religious and socioeconomic cleavage. Pillar parties continue to exercise their role of mobilization and representation of societal segments, but these segments tend to become smaller over time and parties face difficulties in extending their reach beyond their classe gardée. As regards the linguistic cleavage, the N-VA presents itself as the party embodying the Flemish side of the cleavage. With a large, passive membership, one could assume that it plays the role of a new pillar party. However, the party's membership is more ideological than the classic pillar parties, ideological reasons play a more central role in the reasons for joining and members adopt very radical views on the centre-periphery cleavage. Furthermore, the party elite does not share the classic features of consensus seeking and power sharing (Beyens, Deschouwer, van Haute, Verthé, 2015), and they do not have a clear counterpart to build compromises with. Belgian parties are at the crossroads: they have to respond to societal changes and rethink how they can organize 
mobilization and representation while at the same time work with institutions that were conceived for consociational purposes. The question remains whether they will be able to bridge that gap or contribute to deepen it.

These findings are highly relevant for analyses of Belgian politics in which parties traditionally play a dominant role (Deschouwer, 2009). Despite the often-heard message of party decline and the waning of party-based cleavages in society, a general pattern of stability emerges from this article. Parties thus still remain important actors in Belgium's consociational democracy. These findings shed more light on the parties' role and continued dominance, and given the key role of parties in the Belgian democratic system, they give us more insight into the broader political system. Lessons learnt in this article are also relevant for countries beyond Belgium. Other European countries (the Netherlands and Austria, for instance) have also been labelled as consociational democracies, where parties share similar features and similar roles as those in Belgium. Also, in those countries there are indications of a waning role for parties, and it remains to be seen whether this implies also a decline in their consociational features. Our analysis on Belgian parties could inspire similar studies in these countries too.

\section{Note}

1 Owing to the very low response rate of OpenVLD in this survey, we leave them out of the analysis here.

\section{References}

Beyens, S., Deschouwer, K., van Haute, E., Verthé, T. (2015). Born again, or born anew: Assessing the newness of the Belgian political party New-Flemish Alliance (N-VA). Party Politics, 23(4), 389-399.

Billiet, J. (1982). Verzuiling en politiek: theoretische beschouwingen over België na 1945. Belgisch Tijdschrift voor Nieuwste Geschiedenis, 13, 85-118.

Bouteca, N., Devos, C., Van de Voorde, N. (2017). Zijn Vlaamse partijen makelaars of ideologen? Een onderzoek op basis van inhoudelijke opvattingen van partijleden. In B. Wauters (Ed.), Wie is nog van de partij? (pp.81-100). Leuven, Belgium: Acco.

Deschouwer, K. (1994). The decline of consociationalism and the reluctant modernization of Belgian mass parties. In R. S. Katz \& P. Mair (Eds.), How parties organize. Change and adaptation in party organizations in western democracies (pp.80-108). London: Sage.

Deschouwer, K. (2009). The politics of Belgium. New York, Basingstoke: Palgrave Macmillan.

Deschouwer, K. \& Opsomer, M. (1993). Politieke participatie van partijmilitanten. Res Publica, 32(2), 213-219.

Deschouwer, K., Pilet, J.-B., van Haute, E. (2018). Party families in a split party system. In K. Deshouwer (Ed.), Mind the gap. Political participation and representation in Belgium (pp. 91-112). London: Routledge.

Devroe, R., de Vet, B. \& Wauters, B. (2017). De partijbasis als microkosmos? De representativiteit van partijleden onderzocht. In B. Wauters (Ed.), Wie is nog van de partij? (pp. 23-42). Leuven, Belgium: Acco. 
Devroe, R. \& Van de Voorde, N. (2017). Partijactivisme, met lede(n) ogen aanzien. In B. Wauters (Ed.), Wie is nog van de partij? (pp. 43-62). Leuven, Belgium: Acco.

Dewachter, W. (2003). Van oppositie tot elite. Over macht, visie en leiding. Leuven, Belgium: Acco.

Dobbelaere, K. (2017). Religion and politics in Belgium: From an institutionalized manifest catholic to a latent Christian pillar. Politics and Religion Journal, 4(2), 283-296.

Downs, A. (1957). An economic theory on democracy. New York: Harper \& Row.

Fukuyama, F. (1992). The end of history and the last man. New York: Free Press.

Hellemans, S. (1990). De strijd om de moderniteit. sociale bewegingen en verzuiling in Europa sinds 1800. Leuven, Belgium: Universitaire Press.

Huyse, L. (1970). Passiviteit, pacificatie en verzuiling in de Belgische politiek. Een sociologische studie. Antwerpen: Standaard Wetenschappelijke Uitgeverij.

Lijphart, A. (1969). Consociational democracy. World Politics, 21(2), 207-225.

Lijphart, A. (2012). Patterns of democracy. Government forms and performance in thirty-six countries (2nd ed.). New Haven and London: Yale University Press.

Lipset, S. \& Rokkan, S. (Eds.) (1967). Party systems and voter alignments: Cross-national perspectives. New York: Free Press.

Lorwin, V. (1966). Belgium: Religion, class and language in national politics. In R. Dahl (Ed.), Political oppositions in western democracies (pp.147-187). New Haven, CT: Yale University Press.

Luther, K.R. (1999). A Framework for the comparative analysis of political parties and party systems in consociational democracy. In K.R. Luther \& K. Deschouwer (Eds.), Party elites in divided societies (pp. 3-19). London: Routledge.

Marien, S. \& Quintelier, E. (2011). Trends in party membership in Europe. Investigation into the reasons for declining party membership. In E. van Haute (Ed.), Party membership in Europe: Exploration into the anthills of party politics (pp. 43-58). Brussels, Belgium: Editions de l'Université de Bruxelles.

Meguid, B.M. (2005). Competition between unequals: The role of mainstream party strategy in niche party success. American Political Science Review, 99(3), 347-359.

Méndez-Lago, M. (2004). Electoral consequences of (de-) pillarization. In K. Luther \& K. Deschouwer (Eds.), Party elites in divided societies: Political parties in consociational democracy (pp. 191-224). London: Routledge.

Pilet, J.-B. (2005). The adaptation of the electoral system to the ethno-linguistic evolution of Belgian consociationalism. Ethnopolitics, 4(4), 397-411.

Pilet, J.-B. \& Wauters, B. (2014). The selection of party leaders in Belgium. In J.-B. Pilet \& W. Cross (Eds.), The selection of political party leaders in contemporary parliamentary democracies. A comparative study (pp. 30-46). London: Routledge.

Rokkan, S. (1977). Towards a generalized concept of 'verzuiling'. A preliminary note. Political Studies, 25(4), 563-570.

Scarrow, S. (2000). Parties without members? In R. Dalton \& M. Wattenberg (Eds.), Parties without partisans. Political change in advanced industrial democracies (pp. 79-101). Oxford: Oxford University Press.

van Biezen, I., Mair, P. \& Poguntke, T. (2012). Going, going, ... gone? The decline of party membership in contemporary Europe. European Journal of Political Research, 51(1), 24-56.

van Haute, E. (2015). Party membership in Belgium. from the cradle to the grave? In E. van Haute \& A. Gauja (Eds.), Party members and activists (pp. 34-49). London: Routledge.

van Haute, E., Amjahad, A., Borriello, A., Close, C. \& Sandri, G. (2013). Party members in a pillarised partitocracy. An empirical overview of party membership figures and profiles in Belgium. Acta Politica, 48(1), 68-91. 
van Haute, E. \& Paulis, E. (2017). MAPP dataset. Retrieved from https://zenodo.org/ record/61234\#.XITIAVQzbIU.

Wauters, B. (2014). Democratising party leadership selection in Belgium: motivations and decision-makers. Political Studies, 61(1), 61-80.

Wauters, B. (Ed.) (2017). Wie is nog van de partij? Crisis en toekomst van partijleden in Vlaanderen. Leuven, Belgium: Acco.

Weldon, S. (2006). Downsize my polity? The impact of size on party membership and members activism. Party Politics, 12(4), 467-481.

Appendix 1. Overview of surveys of party members in Belgium

\begin{tabular}{|c|c|c|c|c|c|c|c|}
\hline $\begin{array}{l}\text { Party } \\
\text { acro- } \\
\text { nym }\end{array}$ & $\begin{array}{l}\text { Year of } \\
\text { survey }\end{array}$ & Mode & Population & $\begin{array}{l}\text { Sample } \\
\text { size }\end{array}$ & $\begin{array}{l}\text { Valid } \\
\text { responses }\end{array}$ & $\begin{array}{l}\text { Valid/ } \\
\text { sample } \\
\text { (\%) }\end{array}$ & $\begin{array}{l}\text { Valid/ } \\
\text { popu- } \\
\text { lation } \\
(\%)\end{array}$ \\
\hline PS & $\begin{array}{l}\text { November } \\
2003\end{array}$ & $M$ & 82,399 & 2,500 & 822 & 32.9 & 1.0 \\
\hline Ecolo & March 2004 & M & 3,208 & 3,200 & 1,029 & 32.2 & 32.0 \\
\hline VLD & January 2006 & M & 72,475 & 2,500 & 465 & 18.6 & 0.6 \\
\hline$C D \& V$ & June 2006 & M & 83,180 & 2,500 & 604 & 24.2 & 0.7 \\
\hline $\begin{array}{l}\text { OpenVL } \\
\text { D }\end{array}$ & May 2012 & $M+1$ & 66,232 & 1500 & 433 & 28.9 & 0.6 \\
\hline $\mathrm{N}-\mathrm{VA}$ & April 2012 & $M+1$ & 36,439 & 1500 & 983 & 65.5 & 2.7 \\
\hline CD\&V & April 2013 & $M+I$ & 66,031 & 1500 & 666 & 44.4 & \\
\hline Groen & May 2013 & $M+I$ & 7,855 & 1500 & 931 & 62.1 & \\
\hline Sp.a & June 2015 & $M+I$ & & 1500 & 583 & 38.9 & \\
\hline Ecolo & $\begin{array}{l}\text { September } \\
2016\end{array}$ & I & 5,856 & 1 & 627 & & 10.7 \\
\hline$C D \& V$ & April 2018 & I & & 1 & 2,623 & & \\
\hline Groen & June 2018 & I & & 1 & 1,205 & & \\
\hline N-VA & $\begin{array}{l}\text { December } \\
2017\end{array}$ & I & & 1 & 4,260 & & \\
\hline Sp.a & $\begin{array}{l}\text { November } \\
2017\end{array}$ & I & & 1 & 2,684 & & \\
\hline
\end{tabular}

